\title{
Comic Ironic Modes in New Romanian Cinema
}

\author{
By Christina Stojanova
}

Fall 2014 Issue of KINEMA

\section{ETHICS IS THE NEW AESTHETICS: COMIC IRONIC MODES IN NEW ROMANIAN CINEMA}

Irony irritates us because it denies us our certainties by unmasking the world as ambiguity.

- Milan Kundera

Irony indicates saying (or showing) as little as possible

and meaning as much as possible ...

[thereby] relying on complete objectivity and suppression

of all moral judgements.

- Northrop Frye

In a study on the role of irony in New Romanian Cinema (NRC), entitled The New Romanian Cinema Between the Tragic and the Ironic, we referred to the proximity - indeed, interchangeability - of the NRC realism with the tragic and the ironic, which 'sometimes, as in Corneliu Porumboiu's and Radu Jude's films,' colludes with the comedic 'by balancing on the verge of dead-pan black humour, suspense and existential angst' and even absurdity (Stojanova, Duma 2012:14). In light of Northrop Frye's Anatomy of Criticism the article focused on the restricted ability of selected NRC protagonists to 'act vis-à-vis their environment (or society),' and concluded that their plight for social inclusion is overwhelmingly relegated to that of alazons (or impostors) and even worse - to pharmakoi (or scapegoats) - types of character, separated from society and representative of what Frye calls 'tragic ironic modes' (qtd in Stojanova, Duma 2012:13). It is in this 'peculiar narrative space' located between the 'opposite poles' of the 'inevitable irony' of the Nietzschean 'human, all too human' and the 'incongruous irony of human life ... whose archetype is Christ, the perfectly innocent victim, excluded from society', where most of the NRC heroes and anti-heroes are to be found (qtd in Stojanova, Duma 2012: 14). Gravitating mostly towards 'the pole of inevitable irony,' their fate - like that of their champion Joseph K, the hero of Kafka's Trial - is 'not the result of what they have done, but the end of what they are' (qtd in Stojanova, Duma 2012: 14).

Yet in their complexity, the NRC characters are not only pharmakoi(1) and alazons(2), plainly rejected by society, they are also self-deprecating eirons, ${ }^{(3)}$ boastful miles gloriosa ${ }^{(4)}$ or 'clever, likeable but unprincipled' picaros ${ }^{(5)}$ eager to (re)integrate into society, typical of what Frye calls comic ironic modes, and even combinations of both (Frye 1990: 45). Thus depending on the mode, one and the same type of character could be cast as either tragically or comically ironic pharmakos; and the tragically ironic alazon is as easily transformed into a comic miles gloriosus as in picaro. For, while the ironic tragedy emphasizes how the helpless victim endures the pain, undeservedly inflicted on him or her by society (and in the process solicits more pity than fear), at its lower end, dark ironic comedy borders with savagery as it focuses on the various ways of 'inflicting pain on a helpless victim,' thus in its extreme forms evoking more cruel ridicule rather than sympathy (Frye 1990: 45). Towards its lighter end, ironic comedy shifts its focus more towards society than on character and derides it as corrupt and snobbish, or it could even feature a protagonist, who fails or shuns the usual comedic reintegration because he or she proves to be much wiser than the society at hand.

It is to the proximity of the tragic 'inevitable irony' of the NRC realism to the comedic irony of savage black humour, surrealism and absurdity that this essay now turns. First, it looks at the tenuous border between the tragic and the comedic ironic modes through a brief comparison between Cristi Puiu's The Death of Mr. Lăzărescu (Moartea domnului Lăzărescu, Romania, 2005), and Clin Peter Netzer's Medal of Honour (Medalia de onoare, Romania, 2009). Secondly, it scrutinizes Radu Jude's Everybody In Our Family (Toata lumea din familia noastra, Romania-Netherlands, 2012) as a prime example of dark ironic comedy within the context of NRC, spilling into surrealist irony and black humour of films like Puiu's Aurora (Romania, 2010) and Gabriel Achim's Adalbert's Dream (Visul lui Adalbert, Romania, 2011). Then the essay moves towards the lighter end of the comic irony, which is concerned primarily with social ills, by comparing and contrasting Tudor 
Giurgiu Of Snails and Men (Despre oameni si melci), Romania, 2012) to Mircea Daneliuc's The Snails' Senator (Senatorul melcilor, 1995). And finally, the essay concludes with a look at another off-shoot of the lighter ironic comedy, Corneliu Porumboiu's Police, Adjective (Politist, adjectiv, Romania, 2009), featuring a character who, although failing the typical comic reintegration, appears wiser than the rejecting society.

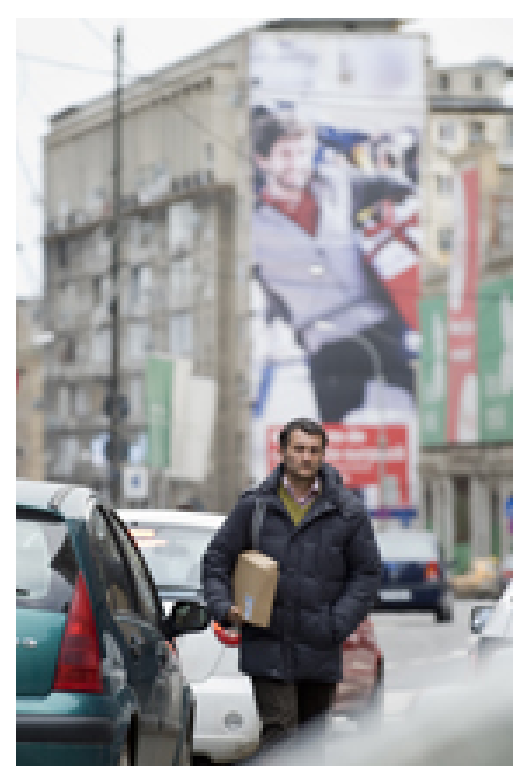

Figure 1: Aurora by Cristi Puiu (2010)

\section{At the Crossroad of Ironic Modes}

The protagonist of The Death of Mr. Lăzărescu is a typical pharmakos, whose abilities to act are restricted by his age and infirmity, and his isolation from society ultimately causes his death. And yet the genre of the film is defined by its English-language trailer as a 'black comedy' not only for marketing purposes. The viewer moves from the playful mirth - solicited by the protagonist's early antics and jokes, as well as by his pompous name, Dante L $\breve{a z a ̆ r e s c u, ~ i r o n i c a l l y ~ s u g g e s t i n g ~ r e s i l i e n c e ~ i n ~ d e a t h ~ a n d ~ a f t e r l i f e ~-~ t o ~ t h e ~ e s c a l a t i o n ~}$ of his misadventures culminating in his death. Mr. Lăzărescu's descent into the hell of the Bucharest hospital system exposes the 'incongruous irony' of a 'perfectly innocent' character's victimization by the very institutions that are meant to help him, thus arousing the viewer's scornful sneer at these institutions, but also enhances the pity for Mr. Lăzărescu's tragic lot.

In Medal of Honour, the viewer is positioned to follow a similar empathic curve, but in a much lighter manner since the hilarity, stemming from the intertwined personal and public ironic discourses, does not end in death and is therefore transformed into sympathy towards this temperate miles gloriosus. The year is 1995, and the protagonist Ion Ion - a retired accountant whose wife has been giving him the silent treatment since it became known he had prevented his only son, now a successful doctor in Canada, from leaving the country clandestinely by informing the communist police - is awarded a medal by the Ministry of Defence. Aware of his brief and far from heroic participation in the second phase of WWII (23 Aug 1944 - 9 May, 1945), when Romania fought against the Germans, Ion Ion embarks on a quest for the reasons of this awarding, only to discover that it was meant for a namesake, who actually fought on the side of Germans during the initial phase of the war (22 June 1941 - Aug 23, 1944). Thanks to the protagonist's hilariously resourceful demarches, the original recipient renounces the medal and - along with a number of ageing former officers of dubious political allegiances, kept under wraps during communism (including a member of the notoriously nationalist and anti-Semitic Iron Guard) - our hero is awarded the medal at a ceremony, presided by the then President Ion Iliescu who (in a self-reflexive ironic twist) plays himself in the film.

However Ion Ion's guilt in appropriating another man's distinction and the moral perks that go with it, pale in comparison to the ensuing sadistic vengeance with which the Ministry's bureaucratic machine punishes 
him. By brutally sequestering the medal which, as the Ministry secretary says, he 'should have taciturnly kept instead of making all this fuss,' the post-communist Romanian institutions - not unlike the Bucharest hospitals in The Death of Mr. Lăzărescu - emerge as the site of 'one of the most terrible ironies known to art, that of the inordinate callousness of a society towards a harmless simpleton, who only wants to impress his wife and win back his son's respect. The last episode features Ion Ion, decorated with a medal he had just bought from a pawn shop, finally taking his place at the Christmas dinner table next to his son and his Canadian family. Instead of exuding pride and joy, however, he bursts into tears of guilt, shame and humiliation. The minimalistic imagery and editing, compounded by the ascetic interpretation of Victor Rebengiuc - one of the best Romanian actors from the older generation - throw in high relief the ironic split between the subjects of sympathy and ridicule, and their resolution into the melodramatic pathos of the finale as a powerful form of social criticism.

\section{The Dark Ironic Comedy: Characters Against Circumstances}

Building on Aristotelian ironic tradition, defined as a punctual communicative mechanism wherein we say one thing to infer another, in her exhaustive study of irony, Linda Hutcheon approximates M. M. Bakhtin's school of dialogism, namely V. N. Voloshinov's understanding that irony is an 'encounter in one voice of two incarnate value judgements and their interference with one another'; a way of 'speaking by contraries', or by contradiction (qtd in Haynes 2006:26). In this 'superimposition or rubbing together of meanings,' Hutcheon writes (19), irony 'comes into being in the interactions between said and unsaid, but also between intention and interpretation, as well as between verbal and visual sign system' (178). It is this rubbing together of contradictory meanings that is intrinsically related to emotional investment, or what Hutcheon calls 'affective charge,' with lesser contradictions producing minimal affective charge and greater contradictions - maximal. Based on this assumption, Hutcheon has drafted a table of 'the nine functions of irony,' ranging 'from the most benign in tone and inferred motivation' to the 'contentious zones,' where irony becomes a 'strategy of provocation and polemics' (Hutcheon 1995: 46-7). Moreover, as 'discursive strategy,' irony, like humour in general, has 'a lot to do with power and dominant discourses' (Hutcheon 1995: 17), whether ideological, social, cultural, or aesthetic. Yet irony seeks not only to reverse power dynamics as some theoreticians of irony and black humour have it (Erickson 1988: 201), but rather to blur (or trans-ideologise) it by 'denying us our certainties by unmasking the world as ambiguity' (qtd in Hutcheon 1995 : 15).

In light of this, both The Death of Mr. Lăzărescu and Medal of Honour feature irony of the 'more benign in tone' kind, where antagonistic ironic contradictions are resolved, respectively, either in the death of the protagonist or in his child-like helplessness, typical for melodrama. Everybody In Our Family, however, represents a more extreme form of ironic comedy, crossing into the territory of the savagery, rife with unresolvable contradictions, where the protagonist externalizes his own hang-ups on those closest to him, using his projections as an excuse for his erratic behaviour. The film follows closely Marius (Serban Pavlu), a divorced thirty-something man, throughout a single day by the end of which he - not unlike Emilian from Principles of Life (Principii de viaţă, Constantin Popescu, Romania, 2010) - would see his life in tatters after having totally failed as a father and a human being. Like Emilian, Marius is an arrogant, self-deceiving alazon, who believes he deserves more than he actually gets from life. An exaggerated version of this obviously common human type for NRC is Viorel from Aurora. This three hours plus quasi-documentary patiently follows in painstakingly long takes a day in the life of its sociopathic protagonist Viorel. Rejected by but also rejecting society, Viorel makes no attempts to re-integrate because he lives in a parallel universe, where it is all right to kill four people out of desperation or in revenge for his divorce. Puiu's deadpan parody of the sensationalist Hollywood rendition of serial killers is among the finest examples of ironic comedy verging on surreal absurdity, but it is also a profound psycho-social commentary on the endemic frustration of divorced men, separated from their children. In a way, Marius' introversion and belligerent defeatism brings him closer to Viorel rather than to the extroverted and successful businessman Emilian.

The highly charged 'oppositional' or 'assailing ironic function' (Hutcheon $1995: 47$ ) here works on two levels - personal and social. In the former case, it stems from the widening gap between Marius' image of himself and his actual behaviour, which gradually descends into verbal and physical violence. Such a 'semantic splitting' is also indicative of 'wider social traumas' (Haynes $2006: 27$ ). In Marius' case, the 'wider social trauma' is the post-communist crisis of masculinity, precipitated mainly by the economic crisis, but also by the advent of western ideas as part of the new dominant political and social discourse. Trying to make 


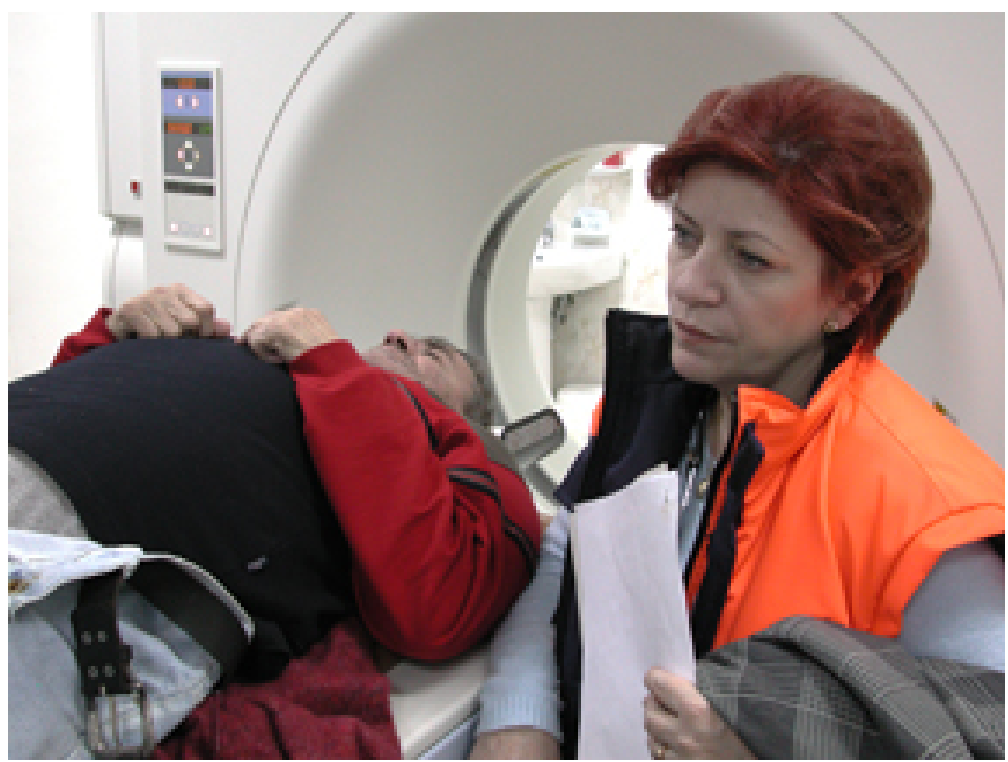

Figure 2: The Death of Mr. Lăzărescu by Cristi Puiu

sense of Romanian post-communist gender issues through the prism of western feminist theories, Shannon Woodcock - an Australian scholar living and working in Bucharest - notes that

[E]lite (government and intellectual) support for the discourses of the European Union thus stands in tension with the post-communist mainstream project of defining gender through "traditional" values as constructed in the Romanian patriarchal matrix (2007: 154).

In other words, Eastern European elites in general - and Romanian in particular - have recommended that Eastern European males abandon summarily their patriarchal attitudes, formed over hundreds of years, and embrace the new and machismo-free western ideas almost overnight. Since this is a task few of them could or want to manage, the overwhelming majority of males stubbornly insist on perpetuating the traditional status quo as a matter of principle. It is this clash between the officially espoused elitist discourse of 'political correctness' and the factual situation on the ground, so to speak, which represents the 'semantic splitting' on an overarching social level and which predicates the acerbic social satire and black humour of Everybody in Our Family.

Other markers of 'semantic splitting,' pointing to even more endemic post-communist 'social traumas' unemployment and underemployment, parents-adult children co-dependence, unravelling of familial bonds are inferred to, verbally or visually, from the moment the badly hung-over Marius, on his way to pick up his five year old daughter Sofia for a week-end at the seaside, drops at his parents' place to borrow their car for the trip. The usual rowdy jokes between father and son quickly degenerate into a full-blown argument about Marius' ex-wife Otilia (Mihaela Sirbu). And while Marius is trying to defend his divorce arrangements as mutually accommodating and 'civilized,' his father, being the unreformed domestic tyrant he is, without mincing words accuses Otilia of making a fool of his son by using Sofia, and worse, thus shaking Marius' already low self-esteem. When he finally gets to Sofia, he finds her still sleeping, jet-lagged and, as both her grandmother and step-father Aurel (Gabriel Spahiu) insist - feverish. Regardless of whether her indisposition is real or, as Marius suspects, just an excuse drummed up by her mother to frustrate him again, it becomes increasingly clear that dragging the child out of town after she has just returned from a vacation abroad is not a good idea.

Yet instead of amending his plans accordingly, Marius, already overwhelmed by conflicting emotions, aroused by his father's earlier harangue and the jealous realization that Sofia is drifting away from him, stubbornly insists that they leave. He seems to have come to regard any compromise through his father's eyes as an un-manly weakness, so when Otilia finally returns, the hell has already broken loose! Minutes after Marius 
has recited affectionate haikus, brought flowers to the grandmother, and generously declared to Sofia that 'everybody in our family will go to Heaven' since all of them - including Aurel and Otilia (but excluding 'an' uncle) - are really good people, he accidentally whacks Aurel's head against the front door, when the latter tries to prevent him from taking the girl on the road. And although Aurel has only suffered a minor bruise, Otilia's animosity for Marius is so great that instead of talking things through with him and Aurel, she calls the police to report domestic violence.

The irony here is that, since Romania joined the European Union in 2007, extraordinary attention has been 'focused on gendered violence in the private sphere' by both scholars and the authorities which, in Woodcock's view, forcefully 'reflects the assumption that the place of women is at home,' thus perpetuating the patriarchal discourse instead of tempering it (154). Yet despite of Otilia's expectations, the authorities' prompt response only exacerbates the situation for Marius, angered by her refusal to withdraw the complaint and anxious about the inevitable legal consequences of the call, is pushed into another round of escalating aggression which - staged like an indie horror movie in its surreal mixture of the hilarious and the scary culminates in gagging and tying together Otilia and Aurel.

In this 'theatre of cruelty' as Artaud once called situations evoking black humour, Grandmother and Granddaughter are denied the privilege of distance, enjoyed by the film viewers, for whom the unfolding events are ridiculous rather than piteous for, as André Breton had it, black humour is the 'mortal enemy of sentimentality' (qtd in Haynes $2006: 27$ ). And yet, disturbingly, most of the abusive action happens in front of Sofia whom, at his lowest moment, Marius asks to stand witness to his foul-mouthed accusations against her mother and Aurel. ${ }^{(6)}$ Unlike The Happiest Girl in the World (Cea mai fericită fată din lume, NetherlandsRomania-France-Japan, 2009), where only the eponymous girl enjoyed some semblance of Jude's empathy, here both Sofia (in the amazingly mature interpretation of little Sofia Nicolaescu) and the grandmother (Tamara Buciuceanu-Botez) are seen as endearing victims - or pharmakoi - who due to their helplessness are totally isolated from society and left on the mercy of three egoistic adults, blinded by power struggle and trampling irresponsibly on each other's feelings.

Indeed, as another theorist of irony and black humour has it, 'with the immediate comedic impact' of the characters' actions, there also emerges a 'countervailing, aesthetic seriousness that interferes with and comments upon the very conditions' of the hilarity produced (Haynes, 2006: 27). It is this 'aesthetic seriousness' that helps Pavlu, Sirbu and Spahiu to bring into focus the ironic clash of growing contradictions between what their characters believe themselves to be in the context of enlightened western gender discourses and what they actually are, thus subverting or trans-ideologising these discourses.

In The Happiest Girl Pavlu appeared as the Director of the commercial, sponsored by the orange juice company, which featured their lottery prize winner - the 'happiest girl' - sitting in her newly won car and ingesting even more juice. Despite his relatively small role, Pavlu was able to prove his mastery over such incongruous sentiments as aggression and vulnerability, posturing and low self-esteem, and paint his character as an up-startish alazon, eager to be recognized as a seasoned film auteur, who scoffs at commercials, yet stoops to the sponsors' whims at the expense of his crew and especially of his non-professional actress, the 'happiest girl.' As Marius, Pavlu has had the very rare opportunity to pursue the widest possible register of human emotions, ranging from his heart-wrenching tenderness for Sofia and desperate last ditch attempts to reclaim Otilia's love or at least her sympathy, to the lowest pit of emotive and physical cruelty towards Otilia and Aurel. It is Pavlu's acting that keeps Marius at the precarious edge between the naturalistically authentic representation of a frustrated ex-husband and an exaggerated caricature thereof. His derisively humiliating escape through the bathroom window with a bleeding head offers no closure to the film, only the dark certainty that this would not be the last of his troubles.

Mihaela Sirbu, just fresh from her breakthrough role in Lucian Georgescu's Fantom Father (Tatal fantoma, Romania, 2011), sustains her part of the reticent, passive-aggressive Otilia in a carefully balanced contrast to Pavlu's explosive temperament, making their marital incompatibility painfully obvious. The irony of her 'semantic splitting' is that, on one hand, she considers herself an emancipated woman, capable of taking care of her mother and daughter on her own but, on the other, indulges her quite conservative desire to rule over a submissive husband, who bends over backwards at her will. Otilia is, or aspiring to be, what Woodcock calls the Romanian 'super woman' - that is, a woman, who in accordance with the older models of 'ideal 
feminine subject,' both 'fulfils her role of sexual object' being 'feminine (beautiful, reproductive),' and is also 'successful in the public sphere as a career woman' (Woodcock 2007: 156). Otilia's family arrangement is actually representative of many a post-communist woman's understanding of western feminist ideas - not as a form of enlightened equality which takes the gender relations to a higher new level, but as a simple reversal of the power dynamics with women now ruling over men with the help of law enforcement, if necessary. Which happens to be traditional men's worst nightmare, thus sealing the impasse of the gender wars.

In this light Gabriel Spahiu as the ostensibly timid Aurel, deserves special attention. In addition to providing an extreme - and thus ironic - narrative contrast to Marius, he is an example of an adaptable selftransformation of traditional machismo into its opposite, but equally unpleasant variety - a domesticated meek creature of neutral gender, at perennial disposal of the women in the house, spineless and soulless. Or is he? For when Marius attacks him with the cork-screw in the kitchen, at first Aurel takes it in silence, but once taped and gagged, he starts screaming at Otilia, blaming the family showdown on her in even more foul - and surprisingly audible despite the gag - language than Marius, thus revealing the true colours of his opportunistic self.

It is hard to imagine another actor in this role but Spahiu, the NRC's superb master of the dead-pan humour and the double entendre - it is enough to recall him as the maladroit and fatalistic safety instructor Fulica Ploscaru in Adalbert's Dream. A veritable eiron - a character, who has given irony its name because of his understated and self-deprecating persona who is also the agent of the happy ending in comedy or catalyst of the tragic catastrophe in tragedy - Ploscaru is trying really hard to stay integrated within his almost surreal social circumstances, not to mention the general absurdity of late Romanian communism, which include a loving wife, children, an eccentric mistress and a boss, who treats him as an errand boy. Predictably for a NCR film, Adalbert's Dream covers a day in Ploscaru's life, and a special one at that he has been long preparing for. As part of the factory celebration of the 65th anniversary of the Romanian Communist Party (PCR), Ploscaru is invited to show two of his amateur $16 \mathrm{~mm}$ shorts on labour safety side by side with congratulatory speeches and songs. Before that, his chaotic itinerary takes him through all kinds of activities, including taking his boss's mother to the doctor. The film is surprisingly authentic in reproducing in detail not only the fashions and the look of the last Ceausescu's years, but also the attitudes and the extant discourses, which are so severely restricted by ubiquitous eavesdropping and informing that all Ploscaru and his colleagues feel comfortable talking about is his bad dream about a fox, and Romania's 1980s goalie Duckadam. Even his ownership of a precious VCR is ideologically suspicious due to its subversive potential to play western films. Ploscaru, however, uses it shrewdly as a parallel currency in exchange for scarce goods and services, pretty much like how Kent cigarettes were used at that time.

The real story of communist censorship and propaganda, which Frye calls 'major arts of the ironic age,' and the fear of repression that made them unusually effective, is to be gleaned from the juxtaposition of Ploscaru's title instructional film - a shaky amateur rendition in the style of the offensively didactic Socialist Realism, the officially prescribed communist aesthetics - to the main narrative (Frye $1990: 47$ ). In a macabre turn of event, worthy of Ionesco, the worker whom Ploscaru has asked on a side to make some souvenir knives for a fee, shuns the celebration to work on these, but cuts off his hand in the process. This episode exposes the mechanism of totalitarianism by foregrounding the blatant contradiction between what Ploscaru propagates officially as a safety instructor and his actions, which have precipitated the accident at one degree of separation. It is this ubiquitous clash between official discourses and reality, or superimposition of contradictory meanings, which Hutcheon calls the 'transgressive' and 'subversive' aspects of 'oppositional' irony (47). The conclusive episode, where Ploscaru is asked to participate in a re-enactment of the accident so it could be used for future safety references, is a chilling parody of Lucian Pintilie's Reconstruction (Reconstituirea, Romania, 1968). Needless to say, in his artistic zeal to make things look more authentic, Ploscaru perishes during the shoot, thus justifying the premonitions of his bad dream.

\section{The Light Ironic Comedy: Circumstances Against Characters}

The ironic modes - both tragic and comic - define not only how the NRC characters fare within a society that mostly rejects them, is indifferent or only accepts them grudgingly. They also grasp the absurdities of post-communist - and in a few films, the late communist - society, which defy and even deconstruct the NRC emblematic 'slice of life' narratives. Yet while in comedies the focus is by (Aristotelian) definition on successful social integration, the NRC ironic comedies - as has been proven so far in this essay - tend to 
subvert this proposition since they pay closer attention to the social, political and economic merit of the circumstances into which the characters wish but are unable to integrate. A good case in point is the ironic take on the post-communist reality in Cristi Puiu's first film, Stuff and Dough (Marfa şi Banii, Romania, 2001), where the so much desired integration of the accidental teenage drug traffickers into the brave new world of criminality and easy money teeters on the verge of farce with its ridiculously ominous coincidences and delays, frustrating their integration. And yet, paradoxically, this preserves not only their moral integrity but also their lives, which disrupts the inherent value judgements on social isolation as negative and social integration as positive.

The Snails' Senator and Of Snails and Men, discussed below, pay particularly meticulous attention to the preoccupations, fears and myths, percolating within their characters' immediate environment. Thus they engage with the political and cultural discourses - elitist, official or mainstream - which inform that environment. And while in the former film, a 'more intense irony is achieved when the humorous society simply disintegrates without anything taking its place as frequently happens in Chekhov,' the latter - as is typical of the 'most ironic phase of comedy' - sees its unworthy society 'triumphant or undefeated' (Frye $1990: 176,177)$.

Of Snails and Men is both a pastiche of and a tribute to Daneliuc's The Snails' Senator, interwoven with romantic comedy, and as such employs functions of benign irony and humour, which Hutcheon calls 'complicating' and 'ludic,' where the contradiction between the superimposed meanings is small. Daneliuc's film, on the other hand, treads dangerously in the contentious zone of the highly charged 'oppositional' and 'assailing' functions, where the ironic clash of contraries results in caustic satire and black humour. Undeniably, the discursive community of viewers that had partaken into the meaning creation of The Snails' Senator has been replaced by a new one, from whose vantage point circa 2012 - due to the painfully protracted 'transitional' period to democracy and market economy - the immediate post-communist aftermath looks either like a paradise lost, or - because of the generational gap - as time immemorial. This explains why a number of Eastern European films looking back at the late 1980s and early 90s have turned with nostalgia and playfully ambiguous irony to the events from that time, as evidenced by the so-called ostalgic trend in German and post-Yugoslavian arts and popular culture and by such NRC films as Cătălin Mitulescu's How I Spent the End of the World (Cum mi-am petrecut sfârşitul lumii, Romania, 2006) and the omnibus Tales from the Golden Age (Amintiri din epoca de aur, Romania-France, 2009).

A brief discussion of narrative tropes and symbols, common to both The Senator's Snails and Of Snails and Men, reveals the mechanism through which their very different ironic approaches operate. The casting of Dorel Visan as an archetypally opportunistic apparatchik in both films is an intriguing entry point to the analysis. In Daneliuc's film Visan plays the title Senator Vartosu, who arrives in the provinces for a ribbon-cutting inauguration of a new hydro-electric dam. A former communist boss turned nouveau riche, the Senator has summarily traded his allegiance to the all-powerful communist party for allegiance (or rather lip-service) to such newly-minted, politically correct dominant discourses as democracy, free market, ethnic and gender equality. His unreformed hedonistic nature, however, plays a bad trick on him - and on the whole local village, for that matter. Thus his exotic desire to have local snails for dinner at which he would also indulge the Swiss TV crew that happens to be staying at the same picturesque retreat, becomes a catalyst for the ensuing nightmarish events, violating just about any of Romania's newly-embraced human rights commitments. And when the villagers are herded up the hills en masse by the local authorities to collect snails, a young teacher is raped by two Roma boys (or by two Tzigani, as the pre-EU discourse had it), and a man dies after being knifed from behind - a death that might or might not be caused by the Roma boys. As a result, the village descends into a fiery murderous mayhem, avidly filmed by the otherwise indifferent Swiss crew. The rubbing of contradictions here creates transgressive and destructive irony on all level since most of what is said is promptly questioned by what is shown. Indeed, as Woodcock writes, 'accession to the EU requires a series of economic, judicial, and social reforms, but while the necessities for equal opportunities' have been reflected in the respective official documents, very little has been done by these same officials to help eradicate the endemic grass-root ethnic tensions (152).

The film ends with the Senator and the Swiss crew fleeing the chaos yet stopping for a last look at the mysterious Ark, being built on the hill-top and arousing superstitious fear and awe in the cynical Senator and his entourage. A nod to the numinous allusions of the 'incongruous irony of human life, whose archetype 
is Christ' (Frye), the Noah Ark serves as - even if a far-fetched - warning that the post-communist deluge would spare no one but the likes of the maverick Ark builder, whose 'mind is governed by the Spirit' (Romans $8: 7)$.

In Giurgiu's film, the ageing Visan is cast as Vladimir, the director of a big plant in the provinces, who is destined to preside over its demise. Over the years, Visan's character's archetypal virility and hedonistic panache have mellowed, but the aggressively opportunistic core of his persona has remained intact and, as it turns out, Vladimir has been fostering semi-criminal designs about the bankrupted plant, involving a couple of French businessmen who are about to arrive in town. The film, built on the irony of contrasts and contradictions, opens with Vladimir preparing a speech addressing the pending plant closure while the TV set in his office broadcasts a reportage on Michael Jackson's Bucharest leg of his 1992 Dangerous Tour. Scenes from the shoot of his music video 'Police Walk' in a Bucharest stadium with Jackson donning a Romanian police officer uniform, surrounded by thousands of extras, are followed by a reportage from his meeting with then President Iliescu - at the time, an inordinate honour for a pop-music celebrity! Sustained by the Jackson coverage both symbolically and politically, the film establishes a hilarious incongruity between the global and the local. It goes on to contrast the overarching hegemony of western entertainment industry - a symbol of the so much desired capitalist paradise - to the ubiquitous post-communist economic crisis, encapsulated metonymically in doomed attempts to preserve the national and the classical artistic heritage: as a welcoming greeting for the French businessmen, the local school-teacher adapts Ravel's Bolero for melodica solo and rhythmic knocking on desks!

Vladimir's arrogant disregard of workers' needs is furthered by the French quotes from the once banned Romanian émigré thinker Emil Cioran he sprinkles his speech with, which alludes to the Francophile fever that had gripped Romanian elites from that time. By contrasting this scene with the next, where one of the workers, the handsome George, is having sex with Vladimir's secretary, the beautiful Manuela on the plant roof-top, Giurgiu introduces yet another layer of ironic hilarity which, in a truly postmodern fashion fuses social satire with the playfulness of a romantic comedy. Needless to say, casting along with Dorel Visan such NRC stars as Andrei Vasluianu (George) and Monica Barladeanu (Manuela), known best for their dramatic even tragic characters - the blindly devoted husband Aurel from The Other Irina (Cealaltă Irina, Andrei Gruzsnitki, Romania, 2009) and the eponymous Francesca, the equally devoted girlfriend of a weak man in Boby Paunescu's first film (Romania 2010) - was a gamble that did pay off generously.

Vladimir's sycophant and conceited dealings with the French businessmen - strongly remindful of Senator Vartosu's ways with the Swiss crew - constitute another intertextual level of irony. In an attempt to conceal the fact that, once sold, the plant would be closed and dismantled, Vladimir starts a rumour that the French will transform its operations in order to produce canned snails (sic!) for export. In the meanwhile Manuela - whose romantic involvement with the younger businessman Olivier progresses all the way through its triumphant resolution with a marriage proposal - informs the workers of Vladimir's true intentions. In yet another romantic twist, Olivier promises to preserve the plant as a wedding present to Manuela, and the film ends with a panoramic shot of the plant workers, herded up the hills en masse to collect snails for export. The sarcastic potential of the superimposition of meanings in this direct visual quote from The Snails' Senator cannot be underestimated. What Daneliuc saw in the early 1990s as an act of public humiliation, inflicted by arrogant powers-that-be, now looks like an acceptable solution to a serious economic impasse after two decades of worsening economy. Especially after the collapse of the back-up plan, initiated by George, according to which the workers were to collect hard currency through sperm donations and thus buy out the plant themselves. This plot-line represents another energetic level of irony, targeting simultaneously a couple of popular manifestations of Balkan machismo - its over-investment in bombastic quick-fixes and in the myth of its inordinate sexual virility. Yet it also blurs or, as Hutcheon has it, trans-ideologises these arrogant certainties with a smart narrative coda. It turns out that the clinic refuses to accept so much domestically produced sperm as the international demand privileges Danish students' sperm donations because of their higher IQs and blue eyes! The film then ends with George reclaiming his estranged wife, although - in a final ironic twist - he has just learned that his sperm was rejected as infertile and he could not have been the biological father of his beloved son.

In Way of Conclusion: Characters Outside Circumstances

Corneliu Porumboiu is the NRC master of dead-pan absurdity, as amply demonstrated by his debut film, 
12:08 East of Bucharest ( $A$ fost sau n-a fost, Romania, 2006) as well as by his third film, When Evening Falls on Bucharest or Metabolism (Când se lasa seara peste Bucuresti sau metabolism, Romania, 2013), which is, reportedly, a tongue-in-cheek meta-cinematic deconstruction of the so much tooted NRC realist aesthetics, revealing in less than twenty long takes the meticulous artifice that goes in staging what would later look on screen as a seamlessly realistic flow of life 'caught unawares' as Dziga Vertov famously had it. ${ }^{(7)}$ It is however his second film, Police, Adjective, which comes closest to Frye's description of a 'very ironic comedy,' whose character fails the proverbial comedic (re) integration yet proves to be much wiser than the rejecting society:

$[\mathrm{T}]$ he more ironic the comedy, the more absurd the society [which is] condemned by or contrasted with, a character that we may call the plain dealer, an outspoken advocate of a kind of moral norm who has the sympathy of the audience (176).

The 'plain dealer,' who consciously bypasses social - or rather institutional - integration in the name of a 'moral norm,' is Cristi, in the understated interpretation of Dragos Bucur, one of the NRC star actors with more than a dozen serious roles since his break-through in Stuff and Dough and in Radu Muntean's Furia (Romania, 2002). Cristi is a young, reticent, plain-clothed police officer who develops scruples over making an arrest. The film dramatizes the question of fairness and justice against the background of the police institutional bureaucracy, which in itself runs counter to the mores of a society which is still heavily marred by the 'malevolent hangover from many years of a police state' (Denby 2010). While in search of evidence Cristi follows a teenage boy suspected of selling hash to his class-mates, he realizes that the boy is just a scapegoat for the corrupt law enforcers, who seize his case as an easy way to demonstrate their effectiveness, while turning a blind eye to much more serious infractions. Porumboiu devotes a lot of screen time watching Cristi tailing the boy, letting us in on the unglamourous, even humiliating aspects of the police procedural. In an interview, Porumboiu even called 'absurd time' his 'devotion to a man watching and waiting' (qtd in Denby 2010).

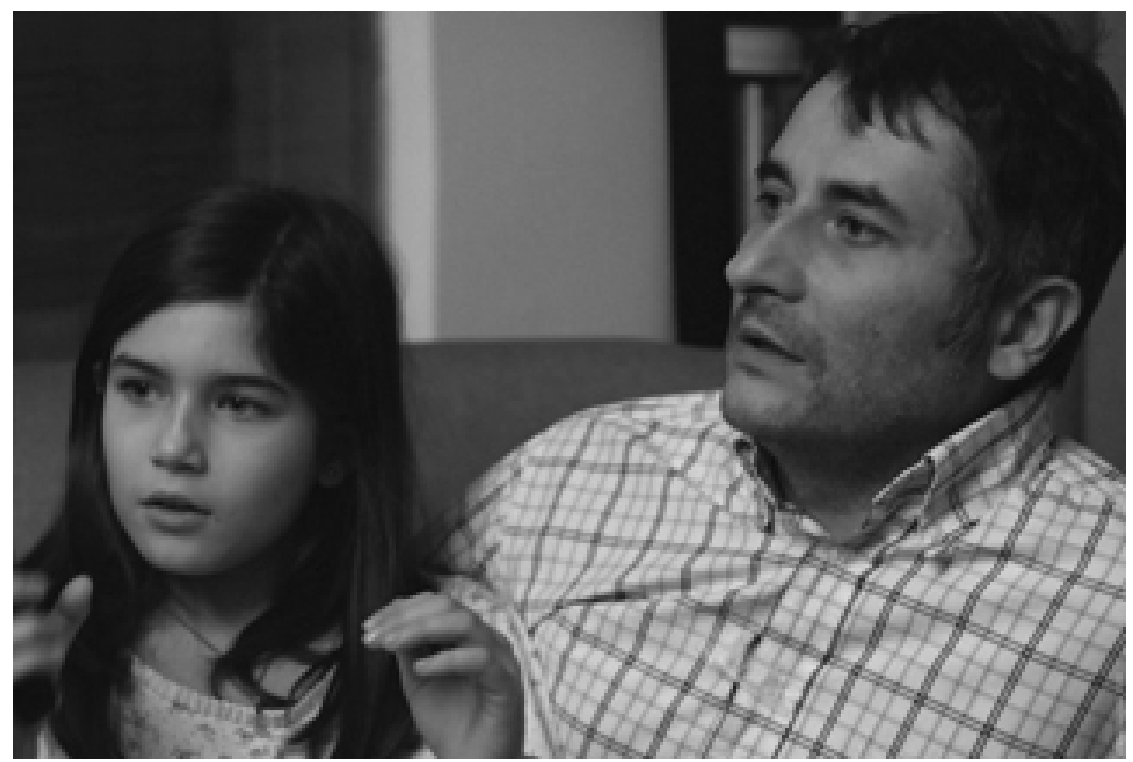

Figure 3: Aurora by Cristi Puiu

Shaped by low contrast lighting (overcast skies, night shots, dim interiors), the mise-en-scène of Police, Adjective serves as an ominous hieroglyph of Ceausescu's era and its aftermath, consistent with its ugliness. The dehumanized (or desacralized as Eliade would have it) interiors and exteriors underscore Cristi's growing existential angst. The intensity of his inner resistance against the short-sighted (and soon to be repealed) law against drug possession and its potential to ruin the kid's life, takes over his whole being. He moves around like an automaton, wearing the same clothes day in and day out, comes home late, eats his cold supper alone and in silence, and rarely attempts to converse with his wife, whom he finds always in front of the computer - either listening to an YouTube recording of a popular love song, or watching a romantic 
film. Their alienation reveals the dynamics of yet another of the NRC unorthodox family pairs, challenging familiar gender stereotypes: Cristi is the sensitive one, while his wife - a philologist by profession - despite her ostensible interest in sentimental entertainment lore, is the rationalist, who feels at home in the intellectual domain of mind games. Moreover, her competency in complex linguistic terms she somewhat condescendingly explains to Cristi prefigures the humiliation he suffers at the finale.

The first part of the film is comprised by an almost hour-long, slow-paced (in)action, whose halted rhythm mirrors the pace of Cristi's awakening conscience. It however turns out to be just a long introduction to the conclusive second part - a more than 15 minute-long episode - whose stasis underscores on narrative, aesthetic and ethical level what Hutcheon calls 'oppositional' ironic clash with the preceding procedural. Summoned by his boss who, obviously bemused by Cristi's insubordination, questions him on the literal meaning of words like 'conscience,' 'police,' 'law' as defined by Romanian dictionary, Cristi is subjected to an intellectual and moral test, whose paradigmatic importance for the NCR films discussed here, cannot be underestimated. The aesthetically risky endeavour of juxtaposing abstract text (written or pronounced) with representational images vindicates Cristi's unravelling when he is pressurized to rationalize his intuitive ethical stance, or what Kant called 'the moral law within' during the public reading from the Romanian terminological dictionary. Cristi's 'best, truest, most generous impulses about justice' are seen 'crushed by authoritarian habits that, embedded in language, remain as strong in the new Romania as they were in the old' (Denby 2010). Indeed, the attempt to remake reality in the image of Hegel's rationality - 'What is real is rational, but not everything that is rational is real' - has been the philosophical foundation of every authoritarian creative destruction, which centres on the full rationality of absolute knowledge.

And yet, Cristi does not suffer a moral defeat thanks to the ambiguity of this scene, which oscillates between biting social satire, black humour and existential desperation, thus blurring or 'trans-ideologising' the power dynamics, and soliciting an unequivocal sympathy for a 'plain dealer' who is much nobler and wiser than the rejecting society. Furthermore, being an intrinsic part of the new 'ethical aesthetics' of the NRC, the ironic strategies, deployed in Police, Adjective and in the other films discussed above, also blur or trans-ideologise the boundaries between the tragic and the hilarious, the particular and the universal, the local and the global (Stojanova, Duma 2012 : 8). Designed to subvert certainties, endorsed by government and elitist discourses, or by traditionalist and mainstream ones, the NRC pharmakoi, alazons, eirons and 'plain dealers' demystify on immediate socio-political level the power dynamics in Romanian post-communist society by exposing its absurdities. On an existential level, however, these ironic strategies challenge the certainties of the human condition by 'unmasking' its universally unsettling ambiguities, which has contributed immensely to the international successes of the New Romanian Cinema.

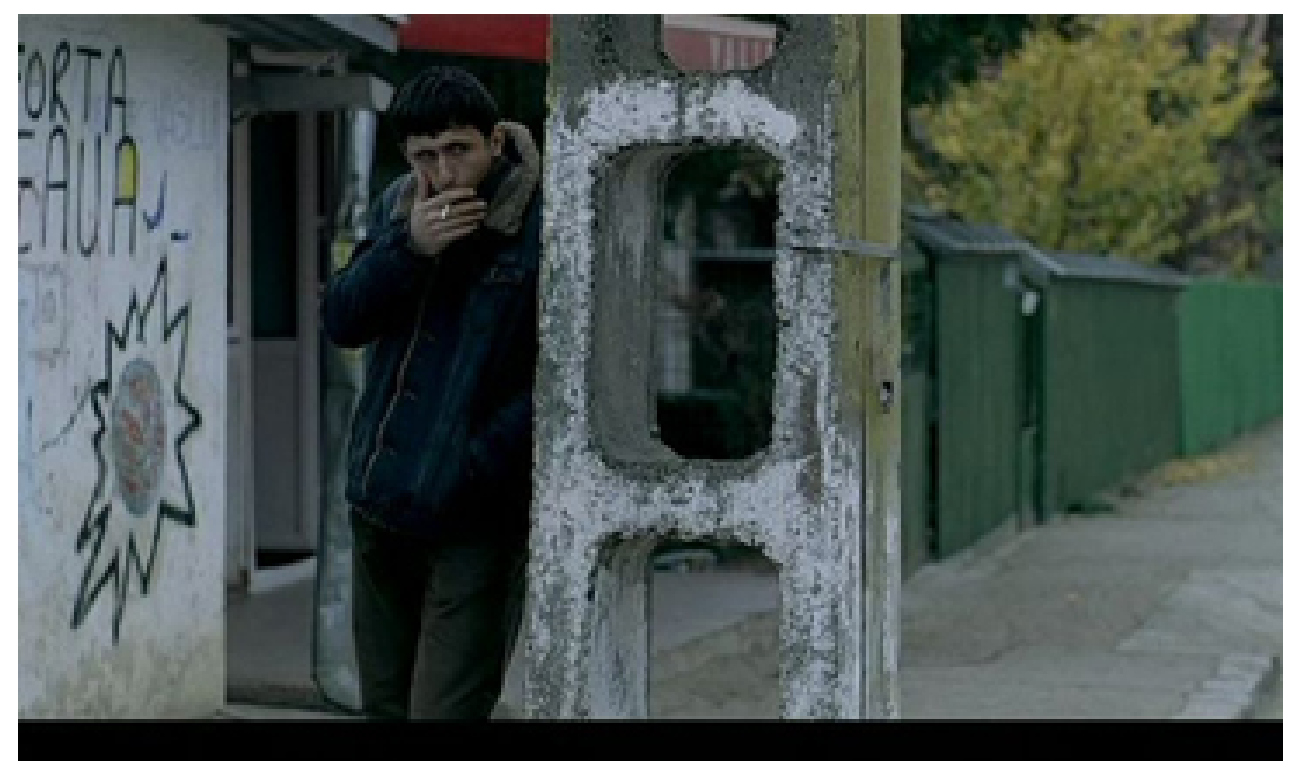

Figure 4: Police, Adjective by Corneliu Porumboiu 


\section{Notes}

1. The character in an ironic fiction who has the role of a scapegoat or arbitrarily chosen victim (Glossary to Anatomy of Criticism, at http://northropfrye-theanatomyofcriticism.blogspot.ca/2009/02/glossary.html)

2. A deceiving or self-deceived character in fiction, normally an object of ridicule in comedy or satire, but often the hero of a tragedy. In comedy he most frequently takes the form of a miles gloriosus or a pedant (Glossary to Anatomy of Criticism).

3. A self-deprecating or unobtrusively treated character in fiction, usually an agent of the happy ending in comedy and of the catastrophe in tragedy (Glossary to Anatomy of Criticism).

4. A comic version of the alazon, or braggart (Glossary to Anatomy of Criticism).

5. Yet another 'comic counterpart' to the alazon (Frye 1995: 45).

6. Judging from little Sofia Nicolaescu's genuine reactions, one tends to doubt whether the young actress was spared all of that mayhem and vulgarity, although such an assumption would unfairly imply that the making of the film is a bleak ironic denial of its own ethical standards, compromised in the name of its aesthetic perfection - an unthinkable compromise for a NRC film, where 'the ethics are truly the new aesthetics' (Stojanova, Duma 2012: 9).

7. See Dimitri Epidis, Toronto International Film Festival Catalog at http://tiff.net/filmsandschedules/festival/2013/wheneveningfallsonbu;

Boyd van Hoeij in Hollywood Reporter at http://www.hollywoodreporter.com/review/evening-falls-bucharest-metabolism-locarno-602652;

Jay Weissberg in Variety at http://variety.com/2013/film/reviews/when-evening-falls-on-bucharest-or-metabolism-review-locarno-filmfestival-1200577482/;

David Hudson in the Locarno Festival daily Keyframe at http://www.fandor.com/blog/daily-locarno-2013-corneliu-porumboius-when-evening-falls-on-bucharest-ormetabolism.

\section{References}

Danby, David (2010). "Men's Laws," in The New Yorker (Feb 1, 2010). Accessed Sept 30, 2013.

http://www.newyorker.com/arts/critics/cinema/2010/02/01/100201crci_cinema_denby\#ixzz1SO9pfNzH.

Erickson, John D. (1988). "Surrealist black humour as oppositional discourse," in Symposium; 4 (3), 1988, 198-215.

Frye, Northrop (1990 [1957]). Anatomy of Criticism, Princeton, NJ: Princeton University Press.

Haynes, Doug (2006). "The persistence of irony: interfering with surrealist black humour," in Textual Practice 20 (1), 2006, 25-47.

Hutcheon, Linda (1994). Irony's Edge: The Theory and Politics of Irony, London \& New York : Routledge Stojanova, Christina \& Dana Duma (1911). "New Romanian Cinema Between the Tragic and the Ironic," in Film International, Intellect UK, 10 (1), 2012, 7-21.

Woodcock, Shannon (2007). "Romanian Women's Discourses of Sexual Violence: Othered Ethnicities, Gendering Spaces," in Living Gender After Communism, edited by Janet Elise Johnson \& Jean C. Robinson, Bloomington and Indianapolis: Indiana University Press, 2007, 149-168.

[Picture Credits: Aurora; Police,Adjective: Mandragora Movies; The Death of Mr. Lazarescu: Tartan USA.] 


\section{Author Information}

Christina STOJANOVA teaches at the Department of Media Production and Studies at the University of Regina, Canada. She has contributed to Cine-bulles, KinoKultura, and the Montreal Gazette. Her publications include chapters in Berlin Culturescapes, Making it Like a Man: Canadian Masculinities, Eastern European Cinema, Traditions in World Cinema, Horror International, Alternative Europe and Cinema and Globalization. 